\title{
Maternal Weight Gain in Pregnancy
}

National Cancer Institute

\section{Source}

National Cancer Institute. Maternal Weight Gain in Pregnancy. NCI Thesaurus. Code C112847.

The last recorded maternal weight prior to birth minus the last recorded weight immediately prior to pregnancy. (reVITALize) 